\title{
Penerapan Membaca Permulaan untuk Meningkatkan Kemampuan Membaca Siswa
}

\author{
Estuning Dewi Hapsari \\ Universitas PGRI Madiun \\ estuning@unipma.ac.id
}

\begin{abstract}
Reading is a language skill that must be mastered by grade 1 students of Ibtidaiyah (MI) Madrasas. This is because almost all textbooks require students to be able to read. Students who cannot read will experience difficulties in the learning process. Students have difficulty understanding the commands and material in the textbook. This study uses a classroom action research design. . The study was conducted at MI Plus Al Islam Dagangan 2018/2019 academic year. Data collection techniques used are observation, interview, and documentation techniques. The type of research data is divided into two, namely process data and outcome data. Process data is used as a tool to measure the quality of the learning process. While the results data are used to determine the level of success of learning. Based on the research findings and discussion, it can be concluded that the application of preliminary reading can improve students' reading skills. The increase is indicated by the average value of students in the first cycle of 51.25 , cycle II 71 and cycle III of 75.8 .
\end{abstract}

Keywords: Read the beginning, reading skills

Abstrak. Membaca merupakan keterampilan berbahasa yang wajib dikuasai oleh siswa kelas 1 Madrasah Ibtidaiyah (MI). Hal tersebut dikarenakan hampir semua buku teks menuntut siswa untuk dapat membaca. Siswa yang tidak dapat membaca akan mengalami kesulitan dalam proses pembelajaran. Siswa kesulitan dalam memahami perintah serta materi di dalam buku teks. Penelitian ini menggunakan rancangan penelitian tindakan kelas (classroom action research). . Penelitian dilakukan di MI Plus Al Islam Dagangan tahun pelajaran 2018/2019. Teknik pengumpulan data yang digunakan adalah teknik observasi, wawancara, dan dokumentasi. Jenis data penelitian terbagi menjadi dua, yaitu data proses dan data hasil. Data proses dijadikan alat untuk mengukur kualitas proses pembelajaran. Sedangkan data hasil digunakan untuk mengetahui tingkat keberhasilan pembelajaran. Berdasarkan temuan penelitian dan pembahasan, maka dapat disimpulkan bahwa penerapan membaca permulaan dapat meningkatkan kemampuan membaca siswa. Peningkatan ditunjukkan dengan nilai rata-rata siswa pada siklus I sebesar 51,25, siklus II 71 dan siklus III sebesar 75,8.

Kata kunci: Membaca permulaan, kemampuan membaca 


\section{PENDAHULUAN}

Keterampilan berbahasa meliputi empat aspek, yaitu membaca, menulis, menyimak, dan berbicara. Berdasarkan keempat kemampuan tersebut, keterampilan membaca merupakan kemampuan wajib yang harus dikuasai oleh siswa kelas 1 SD/MI. Hal tersebut dikarenakan buku teks bagi kelas 1 sudah terdapat berbagai bacaan. Tanpa kemampuan membaca siswa akan mengalami kesulitan untuk memahami perintah ataupun isi buku.

Keterampilan membaca yang dapat diajarkan pada tingkat dasar di MI ialah membaca permulaan. Membaca permulaan bertujuan untuk melatih siswa agar memiliki kemampuan memahami serta meyuarakan tulisan dengan intonasi benar sebagai dasar memelajari membaca lanjut. Dalam pembelajaran membaca permulaan diharapkan siswa dapat mengenali jenis huruf, suku kata, kata, dan kalimat

Henry Guntur Tarigan (2008) menyatakan bahwa mata pelajaran bahasa Indonesia dalam kurikulum CBSA, keberhasilan belajar ditentukan dari kreativitas siswa. Membaca merupakan kunci utama keberhasilan belajar. Jika siswa terlambat dalam belajar membaca maka prestasi yang diperoleh juga akan terhambat. Berdasarkan pernyataan tersebut kemampuan membaca memengaruhi kegiatan belajar mengajar dan prestasi siswa.

Pada kenyataannya masih ada siswa yang belum mampu membaca. Bagi siswa yang belum mampu membaca, mereka tidak dapat memahami perintahperintah yang ada di dalam buku. Dengan demikian siswa menunjukkan ketidaknyamanan dalam belajar dan cenderung bermain sendiri pada saat proses pembelajaran berlangsung.

Perbedaan sikap yang ditunjukkan antara siswa yang mampu membaca dan belum mampu membaca telah meresahkan guru kelas 1. Guru mengalami hambatan dalam proses menyampaikan materi. Hal tersebut karena siswa tidak dapat diperlakukan sama. Bagi siswa yang mampu membaca akan mudah memahami, namun bagi siswa yang belum mampu membaca membutuhkan tuntunan guru yang lebih. Tidak jarang guru harus berpindah dari bangku satu ke bangku yang lain untuk menjelaskan kembali. Keadaan ini membuat proses pencapaian belajar terhambat karena waktu hanya dihabiskan untuk memberikan latihan membaca.

Melihat keadaan tersebut, tuntutan kurikulum sedikit terhambat karena kemampuan siswa untuk membaca masih kurang. Guru harus memberikan perhatian yang lebih bagi siswa yang belum mampu membaca. Tidak jarang proses pembelajaran hanya diisi dengan kegiatan membaca. Hal tersebut sedikit merugikan bagi siswa yang telah lancar membaca.

Berdasarkan hambatan-hambatan yang telah dialami guru kelas 1, akhirnya dibuatlah strategi khusus. Guru memberikan pelajaran tambahan bagi 
siswa yang belum mampu membaca. Siswa diberikan latihan khusus membaca di luar jam pembelajaran. Dengan demikian kemampuan siswa membaca semakin meningkat.

Menurut Solchan T.W. (2009:66) membaca permulaan merupakan kemampuan membaca yang diprioritaskan pada kemampuan membaca tingkat dasar, yaitu kemampuan melek huruf. Maksud dari melek huruf yaitu siswa dapat mengubah dan melafalkan lambang bunyi tulis menjadi bunyi bermakna. Kemampuan selanjutnya ialah meningkatkan kemampuan membaca pada tahap melek wacana. Tahap ini dikatakan sebagai tahap kemampuan yang sesungguhmya karena siswa sudah mampu mengubah lambang tulis menjadi bunyi bermakna yang disetai pemahaman. Berbagai upaya dilakukan oleh guru agar siswa dapat memahami tanda atau simbol dalam membaca permulaan. Upaya menuju kearah pemahaman berkaitan dengan metode membaca yang digunakan. Terdapat dua metode membaca, yaitu metode sintetis dan analisis. Metode sintetis dalam membaca permulaan prosedur diawali dengan memperkenalkan huruf atau suku kata dan kemudian memperkenalkan kata dan kalimat. Sedangkan metode analitis diawali dengan membaca kata atau kalimat dan kembali ke huruf.

Menurut St.Y. Slamet (2008:58), kemampuan membaca permulaan akan berpengaruh pada keterampilan membaca selanjutnya. Hal tersebut dikarenakan membaca permulaan merupakan kemampuan dasar yang harus dikuasai oleh anak. Membaca dapat meningkatkan daya pikir, mempertajam penalaran, mencapai kemajuan, dan meningkatkan diri.

Menurut Iskandarwassid (2008) tujuan membaca permulaan yaitu, (1) mengemali lambang atau simbol bahasa, (2) mengenali kata dan kalimat, (3) menemukan ide pokok dan kata kundi, (4) menceritakan kembali isi bacaan pendek. Adapun tujuan membaca permulaan sesuai kurikulum 2013 tercermin dalam kompetensi dasar, hasil belajar, dan indikator aspek membaca dan menulis untuk kelas I. Adapun standar kompetensi aspek membaca di kelas I sekolah dasar ialah siswa mampu membaca dan memahami teks pendek dengan cara membaca lancar (bersuara) dan membaca nyaring beberapa kalimat sederhana.

Berdasarkan paparan permasalahan di atas, maka membaca permulaan menjadi tahapan yang harus dilalui oleh siswa kelas 1 MI. Pada tahap membaca permulaan, siswa belajar untuk memeroleh kemampuan serta teknik membaca dan mengangkap isi bacaan dengan baik. Maka dari itu, guru harus mampu merancang pembelajaran yang baik agar mampu menumbuhkan kebiasaan membaca sebagai sesuatu yang menyenangkan.

\section{METODE}

Penelitian ini menggunakan rancangan penelitian tindakan kelas (classroom action research). Penelitian ini terbagi dalam tiga siklus. Tahapan pada setiap 
siklus meengikuti model Kurt Lewin (dalam wiriatmaja, 2008) yaitu (1) tahap perencanaan (planning), (2) tahap aksi atau tindakan (acting), (3) tahap observasi (observing), dan (4) tahap refleksi (reflecting). Penelitian dilakukan pada akhir semester 1 di MI Plus Al Islam Dagangan tahun pelajaran 2018/2019.

Teknik pengumpulan data menggunakan observasi, wawancara, dan dokumentasi. Observasi diterapkan pada saat proses belajar mengajar. Wawancara dilakukan untuk memeroleh data sebagai perbaikan siklus sebelumnya. Dokumentasi berupa RPP dan data nilai membaca siswa.

Jenis data berupa data proses dan data hasil. Data proses berupa catatan lapangan hasil observasi, angket, hasil wawancara, dan dokumentasi. Data proses digunakan untuk mengatahui kualitas proses pembelajaran. Data proses dianalisis sebagai berikut.

$$
P=\frac{F x}{N} X 100 \%
$$

Keterangan:

$\mathrm{P} \quad$ : persentase aktivitas guru dan siswa

f : frekuensi kejadian yang muncul

$\mathrm{N} \quad$ : jumlah keseluruhan

Data hasil berupa tes kemampuan membaca siswa. Penilaian hasil digunakan untuk mengetahui tingkat penguasaan materi. Penilaian hasil belajar dianalisis sebagai berikut.

$$
M=\sum \frac{F x}{N}
$$

Keterangan:

M : jumlah rata-rata

Fx : jumlah seluruh nilai dalam kelas

$\mathrm{N} \quad$ : jumlah siswa

\section{HASIL DAN PEMBAHASAN}

\section{Pra Tindakan}

Kegiatan yang dilakukan pada tahap awal adalah observasi pra tindakan. Kegiatan ini dilakukan untuk mengidentifikasi masalah yang dihadapi guru saat pembelajaran berlangsung. Data hasil observasi dijadikan sebagai dasar dalam tindakan penelitian. Adapun hasil observasi dipaparkan sebagai berikut. 


\section{Kondisi Pembelajaran Kelas 1D MI Plus AL Islam Dagangan}

Jumlah siswa kelas I D MI Plus Al Islam Dagangan sebanyak 24 siswa. Siswa laki-laki berjumlah 19 dan siswa perempuan berjumlah 5 siswa. Usia siswa antara 6,4 -7,5 tahun. Pada awal pembelajaran, kemampuan membaca permulaan pada siswa kelas 1D pada umumnya masih belum lancar. Hal tersebut diketahui dari hasil tes masuk. Pada kelas tersebut hasil tes siswa dari materi membaca masih kurang.

Pada proses pembelajaran, keadaan kelas tidak menentu. Hal tersebut dikarenakan ada sebagian siswa yang tidak memerhatikan penjelasan guru. Kondisi yang demikian membuat guru harus menenangkan siswa yang tidak memerhatikan agar pembelajaran dapat dilanjutkan. Ketika siswa sudah tenang guru kembali melanjutkan proses pembelajaran.

Pada akhir pembelajaran, guru selalu memberikan soal atau tes kepada siswa. Berdasarkan hasil tes, terdapat beberapa siswa yang dianggap nilainya kurang. Guru mengidentifikasi bahwa siswa yang nilainya kurang adalah siswa yang tidak mendengarkan penjelasan guru sehingga nilai akhir kurang baik. Berdasarkan nilai tersebut guru mengkaji latar belakang permasalahannya. Ditemukan bahwa siswa yang ramai dan tidak memerhatikan karena siswa belum mampu membaca lancar. Ketidaklancaran siswa dalam membaca menyebabkan siswa tidak mampu memahami soal. Dengan demikian, siswa tidak dapat mengerjakan soal dan nilainya kurang. Kemampuan membaca siswa dipaparkan sebagai berikut.

Tabel 1 Kemampuan Awal Membaca Siswa

\begin{tabular}{llc}
\hline No. & Kemampuan Membaca & $\begin{array}{c}\text { Jumlah } \\
\text { Siswa }\end{array}$ \\
\hline 1 & Menggabungkan huruf menjadi kata & 1 \\
\hline 2 & Mengeja suku kata menjadi kata & 8 \\
\hline 3 & Menggabungkan kata menjadi kalimat & 10 \\
\hline 4 & $\begin{array}{l}\text { Mengeja suku kata menjadi kata dan kalimat. Pada } \\
\text { proses membuat kalimat sudah mulai terdapat akhiran. }\end{array}$ & 5 \\
\hline
\end{tabular}

Berdasarkan hasil analisis tentang kemampuan membaca siswa kelas 1D MI Plus Al Islam Dagangan dalam membaca permulaan masih kurang. Dari 24 siswa hanya terdapat 5 siswa yang sudah mampu mengeja kata menjadi kalimat dan ditambahkan akhiran. Ketidaklancaran membaca atau tingkat kemampuan membaca yang kurang lancar membuat siswa tidak dapat memahami isi buku teks dan pembelajaran sulit dikendalikan. Dengan demikian, nilai siswa selalu di bawah nilai ketuntasan. Nilai siswa banyayang tidak mencapai KKM. 
Kondisi kemampuan membaca siswa memerlukan tindakan oleh guru. Tindakan yang dilakukan harus memertimbangkan sikap siswa selama pembelajaran berangsung berdasarkan observasi pra tindakan. Menurut Rachim (2011) mengemukakan terdapat beberapa faktor yang dapat memengaruhi kemampuan membaca seseorang yaitu dari faktor psikologis motivasi, minat, dan kematangan sosial ekonomi, serta penyesuaian diri. Maka dari itu peran guru sangat penting untuk dapat memotivasi siswa.

\section{Menghadapi Kendala-Kendala Tingkat Kemampuan Membaca Siswa Kelas 1D MI Plus Al Islam Dagangan}

Berdasarkan hasil observasi diperoleh data kemampuan membaca siswa. Hasil tersebut digunakan peneliti untuk menentukan langkah-langkah menghadapi permasalahan kemampuan membaca siswa. Beberapa cara yang ditempuh dipaparkan sebagai berikut.

a. mengadakan pendekatan dengan wali murid. Proses pendekatan diawali dengan adanya komunikasi langsung ketika orang tua menjemput siswa. Guru mengajak wali murid untuk bersama-sama memberikan bimbingan dalam selama berada di lingkungan keluarga khususnya bimbingan dalam belajar membaca.

b. Siswa yang belum mampu membaca diberikan waktu tambahan belajar di sekolah dan diberikan pelajaran khusus membaca. Adapun dalam pelajaran tambahan guru lebih menekankan pada pemahaman bentuk huruf dan kemampuan mengeja serta membaca. Pelajaran ditekankan pada usaha meningkatkan kemampuan membaca permulaan siswa agar mampu membaca.

\section{Paparan data siklus I}

Prosedur Pembelajaran Membaca Permulaan Siswa Kelas 1D MI Plus Al Islam Dagangan

Paparan pelaksanaan tindakan berisi seluruh kegiatan yang terjadi di kelas atau di lapangan pada saat tindakan dilaksanakan. Tindakan yang dilakukan merupakan upaya agar permasalahan yang selama ini dihadapi guru dan siswa dapat teratasi. Tindakan siklus I dilaksanakan selama tiga kali pertemuan di kelas. Pelaksanaan tindakan dipaparkan sebagai berikut.

Pada awal pertemuan, guru memeriksa kesiapan siswa untuk belajar. Guru masuk kelas kemudian mengucapkan salam dan mencatat presensi siswa. Siswa diingatkan kembali mengenai hal-hal yang berkaitan dengan huruf dan kata yang pernah dipelajari Guru kemudian mempersiapkan media pembelajaran yang akan digunakan dan menyampaikan tujuan pembelajaran. Media pembelajaran berupa gambar. Pelaksanaan pembelajaran membaca diawali dengan menyusun huruf 
menjadi kata sesuai media yang digunakan. Merangkai dan membaca kata menjadi kalimat pendek.

Pelaksanaan pembelajaran membaca permulaaan disesuaikan dengan pelajaran bahasa Indonesia. Pelaksanaan tersebut disesuaiakan dengan kompetensi dasar yang ada. Instrumen pembelajaran terdiri dari lembar observasi siswa, lembar penilaian, dan soal tes, serta media pembelajaran yang dapat menunjang kelancaran pelaksanaan pembelajaran yaitu kartu huruf dan media konkret berupa benda-benda di sekitar.

Pada kegiatan inti, guru meminta siswa membuka buku pelajaran. Guru bersama siswa bersama-sama membaca teks pendek yang ada dalam buku pelajaran. Langkah berikutnya, siswa membaca teks bersama-sama tanpa bantuan guru. Kegiatan tersebut membuat anak yang belum lancar membaca merasa kesulitan mengikuti pelajaran. Hal tersebut tampak dari raut wajah yang bingung, mencoret-coret buku dan memainkan alat tulisnya.

Berdasarkan keadaan siswa yang mulai tidak kebingungan, guru mulai mengawali kegiatan membaca dari awal. Tahapan kegiatan tersebut sebagai berikut.

a. Mengenalkan huruf berdasarkan simbol dengan menekankan keteraturan kaitan antara huruf dan bunyi. Tujuannya adalah siswa dapat membunyikan apapun yang tertulis meskipun tidak berupa kata.

b. Pengajaran membaca menggunakan bantuan simbol. Simbol tersebut dimulai dengan pengenalan nama huruf dan bunyinya. Kemudian, dilanjutkan dengan menggabungkan huruf menjadi suku kata, kata, dan kalimat.

c. Mengenalkan kata berdasarkan makna lebih ditekankan pada kemampuan mengenal dan membaca kata-kata yang bermakna.

d. Program pengajaran membaca menggunakan pendekatan berdasarkan makna, dimulai dari kata-kata yang paling sering digunakan dalam kehidupan seharihari. Hal tersebut dikarenakan bahwa kata-kata yang lebih sering dipakai pasti dikenal sehingga mudah untuk mempelajarinya. Siswa didorong untuk belajar membaca melalui berbagai sarana dan alat bantu seperti gambar, kartu huruf, dan sebaginya.

Tabel 2 Penilaian Proses Pembelajaran Siklus I

\begin{tabular}{lllcccc}
\hline & & & \multicolumn{2}{c}{ Pengamat 1 } & \multicolumn{2}{c}{ Pengamat 2 } \\
No. & Aktivitas Yang diamati & Skor & $\begin{array}{c}\text { Persentase } \\
\text { kemunculan }\end{array}$ & Skor & $\begin{array}{c}\text { Persentase } \\
\text { kemunculan }\end{array}$ \\
\hline 1 & $\begin{array}{l}\text { Aktif dalam kegiatan } \\
\text { pembelajaran }\end{array}$ & 5 & 10.0 & 4 & 8.0 \\
\hline 2 & $\begin{array}{l}\text { Bekerja sama } \\
\text { teman }\end{array}$ & dengan & 3 & & 4 & 6.0 \\
\hline 3 & Bertanya kepada teman & 3 & 6.0 & 4 & 6.0 \\
\hline
\end{tabular}




\begin{tabular}{|c|c|c|c|c|c|}
\hline & $\begin{array}{l}\text { tentang } \\
\text { pembelajaran }\end{array}$ & & & & \\
\hline 4 & $\begin{array}{l}\text { Bertanya kepada guru } \\
\text { tentang } \\
\text { pembelajaran }\end{array}$ & 5 & 10.0 & 5 & 10.0 \\
\hline 5 & $\begin{array}{l}\text { Menjawab pertanyaan } \\
\text { teman }\end{array}$ & 4 & 8.0 & 4 & 8.0 \\
\hline 6 & $\begin{array}{l}\text { Menjawab pertanyaan } \\
\text { guru }\end{array}$ & 5 & 10.0 & 5 & 10.0 \\
\hline 7 & $\begin{array}{l}\text { Mengemukakan pendapat } \\
\text { dengan inisiatif sendiri }\end{array}$ & 4 & 8.0 & 4 & 8.0 \\
\hline 8 & $\begin{array}{l}\text { Menghargai teman yang } \\
\text { sedang berpendapat }\end{array}$ & 4 & 8.0 & 4 & 8.0 \\
\hline 9 & $\begin{array}{lr}\text { Membangun } & \text { sendiri } \\
\text { pengetahuan } & \text { yang } \\
\text { dimiliki } & \\
\end{array}$ & 3 & 6.0 & 5 & 6.0 \\
\hline 10 & $\begin{array}{l}\text { Menyelesaikan tugas } \\
\text { yang sedang diberikan }\end{array}$ & 5 & 10.0 & 5 & 10.0 \\
\hline \multicolumn{2}{|c|}{ Jumlah } & 41 & 82,0 & 40 & 80,0 \\
\hline \multicolumn{2}{|c|}{ Rata-rata } & & & & $81 \%$ \\
\hline
\end{tabular}

Berdasarkan tabel di atas diketahui bahwa sikap siswa dalam mengikuti proses pembelajaran cukup baik. Perolehan skor dari pengamat 1 memberikan skor 41 dan pengamat 2 memberikan skor 40. Hasil observasi terhadap aktivitas siswa pada siklus II mencapai $81 \%$ dengan skor rata-rata 40,5. Selama mengikuti proses pembelajaran siswa masih dapat dikendalikan. Hasil dari pembelajaran membaca permulaan dapat dilihat dalam tabel berikut.

Tabel 3 Hasil Pembelajaran Membaca Permulaan Siklus I

\begin{tabular}{lllll}
\hline No. & Nama & Nilai & Persentase & Keterangan \\
\hline 1 & AR & 60 & 4.4 & Belum Tuntas \\
\hline 2 & AA & 50 & 3.7 & Belum Tuntas \\
\hline 3 & AD & 55 & 4.0 & Belum Tuntas \\
\hline 4 & AD & 55 & 4.0 & Belum Tuntas \\
\hline 5 & DA & 65 & 4.8 & Belum Tuntas \\
\hline 6 & DL & 55 & 4.0 & Belum Tuntas \\
\hline 7 & FT & 50 & 3.7 & Belum Tuntas \\
\hline 8 & HW & 55 & 4.0 & Belum Tuntas \\
\hline 9 & IU & 60 & 4.4 & Belum Tuntas \\
\hline 10 & KS & 60 & 4.4 & Belum Tuntas \\
\hline 11 & MF & 60 & 4.4 & Belum Tuntas \\
\hline 12 & MT & 50 & 3.7 & Belum Tuntas \\
\hline 13 & MI & 60 & 4.4 & Belum Tuntas \\
\hline
\end{tabular}




\begin{tabular}{lllll}
\hline 14 & RM & 60 & 4.4 & Belum Tuntas \\
\hline 15 & RA & 55 & 4.0 & Belum Tuntas \\
\hline 16 & SB & 60 & 4.4 & Belum Tuntas \\
\hline 17 & SW & 60 & 4.4 & Belum Tuntas \\
\hline 18 & S & 60 & 4.4 & Belum Tuntas \\
\hline 19 & VF & 50 & 3.7 & Belum Tuntas \\
\hline 20 & WM & 60 & 4.4 & Belum Tuntas \\
\hline 21 & YU & 50 & 3.7 & Belum Tuntas \\
\hline 22 & YD & 55 & 4.0 & Belum Tuntas \\
\hline 23 & ZA & 60 & 4.4 & Belum Tuntas \\
\hline 24 & SC & 60 & 4.4 & Belum Tuntas \\
\hline Jumlah & 1365 & & \\
\hline Rata-Rata & 56,9 & & \\
\hline
\end{tabular}

Berdasarkan tabel hasil tindakan siklus I diketahui bahwa terjadi peningkatan cukup baik. Terlihat dari nilai siswa yang mengalami peningkatan dari kegiatan pra tindakan. Nilai rata-rata siswa meningkat dari 51,25 menjadi 56,8 meskipun nilai siswa belum tuntas. Namun hasil tersebut dikatakan baik karena kondisi kemampuan membaca awal siswa dikatakan kurang.

Pada kegiatan penutup dilakukan refleksi. Guru menanyakan materi yang telah dipelajari dan menanyakan tugas pada pertemuan selanjutnya. Siswa merespon pertanyaan guru. Refleksi digunakan untuk melihat tingkat pemahaman siswa terhadap materi yang sudah diajarkan.

Pelaksanaan siklus I diakhiri dengan adanya tahap refleksi tindakan. Hal tersebut dilakukan untuk mengetahui tingkat keberhasilan dan acuan perbaikan siklus berikutnya. Berdasarkan hasil refleksi, rencana perbaikan siklus II dipaparkan sebagai berikut.

Tabel 4 Hasil refleksi siklus I

\begin{tabular}{llll}
\hline No & Kekurangan pembelajaran & Tindakan perbaikan \\
\hline 1 & $\begin{array}{l}\text { Kondisi kelas cukup ramai dalam } \\
\text { proses pembelajaran karena terdapat } \\
\text { siswa yang bingung,mencoret-coret } \\
\text { buku, dan memainkan alat tulis. }\end{array}$ & $\begin{array}{l}\text { Melakukan proses pembelajaran } \\
\text { membaca sesuai tahap awal. }\end{array}$ \\
\hline 2 & $\begin{array}{l}\text { Mengenalkan huruf berdasarkan } \\
\text { symbol terdapat siswa yang tidak } \\
\text { mau mengikuti }\end{array}$ & $\begin{array}{l}\text { Membuat siswa aktif mengikuti } \\
\text { setiap proses pembelajaran. }\end{array}$ \\
\hline 3 & $\begin{array}{l}\text { Terdapat beberapakata yang } \\
\text { dikenalkan tidak diketahui } \\
\text { maknanya oleh siswa }\end{array}$ & $\begin{array}{l}\text { Menyajikan kata-kata yang } \\
\text { maknanya diketahui siswa. (kata-kata } \\
\text { yang digunakan dalam kegiatan } \\
\text { sehari-hari). }\end{array}$ \\
\hline
\end{tabular}




\section{Paparan Data Siklus II}

Pada proses pembelajaran siklus II kondisi siswa cukup kondusif. Siswa memerhatikan instruksi guru. Siswa mulai menirukan kata-kata yang terdapat dalam gambar dan membaca huruf yang ada di bawah gambar. Siswa juga mulai menyusun kata-kata menjadi kalimat dan memahami arti setiap kata yang dibaca. Berikut paparan penilaian proses siklus II.

Tabel 5 Penilaian Proses Pembelajaran Siklus II

\begin{tabular}{|c|c|c|c|c|c|}
\hline \multirow[t]{2}{*}{ No. } & \multirow[t]{2}{*}{ Aktivitas Yang diamati } & \multicolumn{2}{|c|}{ Pengamat 1} & \multicolumn{2}{|c|}{ Pengamat 2} \\
\hline & & Skor & $\begin{array}{c}\text { Persentase } \\
\text { kemunculan }\end{array}$ & Skor & $\begin{array}{c}\text { Persentase } \\
\text { kemunculan }\end{array}$ \\
\hline 1 & $\begin{array}{l}\text { Aktif dalam kegiatan } \\
\text { pembelajaran }\end{array}$ & 5 & 10 & 4 & 8 \\
\hline 2 & $\begin{array}{l}\text { Bekerja sama dengan } \\
\text { teman }\end{array}$ & 4 & 8 & 4 & 8 \\
\hline 3 & $\begin{array}{lll}\text { Bertanya kepada } & \text { teman } \\
\text { tentang } & \text { materi } \\
\text { pembelajaran } & \\
\end{array}$ & 3 & 6 & 3 & 6 \\
\hline 4 & $\begin{array}{l}\text { Bertanya kepada guru } \\
\text { tentang } \\
\text { pembelajaran }\end{array}$ & 5 & 10 & 5 & 10 \\
\hline 6 & $\begin{array}{ll}\text { Menjawab } & \text { pertanyaan } \\
\text { teman } & \\
\text { Menjawab } & \text { pertanyaan } \\
\text { guru } & \end{array}$ & 4 & 10 & 4 & 10 \\
\hline 7 & $\begin{array}{l}\text { Mengemukakan pendapat } \\
\text { dengan inisiatif sendiri }\end{array}$ & 4 & 8 & 4 & 8 \\
\hline 8 & $\begin{array}{l}\text { Menghargai teman yang } \\
\text { sedang berpendapat }\end{array}$ & 4 & 8 & 4 & 8 \\
\hline 9 & $\begin{array}{l}\text { Membangun sendiri } \\
\text { pengetahuan yang dimiliki }\end{array}$ & 4 & 8 & 4 & 8 \\
\hline 10 & $\begin{array}{l}\text { Menyelesaikan tugas yang } \\
\text { sedang diberikan }\end{array}$ & 4 & 8 & 4 & 8 \\
\hline Juml & & 42 & 84 & 41 & 82 \\
\hline Rata & & & 41,5 & & $83 \%$ \\
\hline
\end{tabular}

Data hasil observasi siklus II menunjukkan bahwa aktivitas siswa dalam pembelajaran siklus II dengan kriteria sangat baik. Perolehan skor dari pengamat 1 memberikan skor 42 dan pengamat 2 memberikan skor 41 . Hasil observasi terhadap aktivitas siswa pada siklus II mencapai $83 \%$ dengan skor rata-rata 41,5. Selama mengikuti proses pembelajaran siswa aktif dan sangat antusias. Siswa bersemangat mengikuti setiap proses pembelajaran.Sedangkan nilai siswa siklus II dipaparkan sebagai berikut. 
Tabel 6 Hasil Pembelajaran Membaca Permulaan Siklus II

\begin{tabular}{|c|c|c|c|c|}
\hline No. & Nama & Nilai & Persentase & Keterangan \\
\hline 1 & AR & 75 & 4.4 & Tuntas \\
\hline 2 & $\mathrm{AA}$ & 60 & 3.5 & Belum Tuntas \\
\hline 3 & $\mathrm{AD}$ & 70 & 4.1 & Tuntas \\
\hline 4 & $\mathrm{AD}$ & 70 & 4.1 & Tuntas \\
\hline 5 & DA & 80 & 4.7 & Tuntas \\
\hline 6 & DL & 75 & 4.4 & Tuntas \\
\hline 7 & FT & 60 & 3.5 & Belum Tuntas \\
\hline 8 & HW & 65 & 3.8 & Belum Tuntas \\
\hline 9 & IU & 70 & 4.1 & Tuntas \\
\hline 10 & $\mathrm{KS}$ & 80 & 4.7 & Tuntas \\
\hline 11 & $\mathrm{MF}$ & 80 & 4.7 & Tuntas \\
\hline 12 & MT & 60 & 3.5 & Belum Tuntas \\
\hline 13 & MI & 75 & 4.4 & Tuntas \\
\hline 14 & $\mathrm{RM}$ & 80 & 4.7 & Tuntas \\
\hline 15 & RA & 70 & 4.1 & Tuntas \\
\hline 16 & SB & 70 & 4.1 & Tuntas \\
\hline 17 & SW & 80 & 4.7 & Tuntas \\
\hline 18 & $\mathrm{~S}$ & 75 & 2.9 & Tuntas \\
\hline 19 & VF & 50 & 2.9 & Belum Tuntas \\
\hline 20 & WM & 70 & 4.1 & Tuntas \\
\hline 21 & YU & 65 & 3.8 & Belum Tuntas \\
\hline 22 & YD & 70 & 4.1 & Tuntas \\
\hline 23 & $\mathrm{ZA}$ & 75 & 4.4 & Tuntas \\
\hline 24 & $\mathrm{SC}$ & 80 & 4.7 & Tuntas \\
\hline \multicolumn{2}{|c|}{ Jumlah } & 1705 & & \\
\hline \multicolumn{2}{|c|}{ Rata-rata } & 71 & $75 \%$ & \\
\hline
\end{tabular}

Berdasarkan tabel tersebut terlihat jika nilai rata-rata siswa meningkat dari 56,9 menjadi 71 . Nilai ketuntasan siswa mencapai $75 \%$. Siswa yang nilainya mencapai 70 dalam ketentuan sekolah atau KKM sekolah sudah dinyatakan tuntas. Berdasarkan kondisi tersebut maka tindakan siklus III perlu dilakukan karena masih masih terdapat siswa yang belum tuntas.

Adapun refleksi tindakan siklus II akan dijadikan sebagai pijakan perbaikan siklus III. Hal tersebut dilakukan agar tingkat keberhasilan pada siklus berikutnya meningkat. Berdasarkan hasil refleksi, rencana perbaikan dipaparkan sebagai berikut. 


\section{Paparan Data Siklus II}

\section{Tabel 7 Hasil refleksi siklus II}

\begin{tabular}{llrll}
\hline No & \multicolumn{2}{c}{ Kekurangan pembelajaran } & \multicolumn{2}{c}{ Tindakan perbaikan } \\
\hline 1 & $\begin{array}{l}\text { Kondisi kelas cukup kondusif, } \\
\text { namun terdapat beberapa siswa yang } \\
\text { pasif dan tidak mengikuti kegiatan } \\
\text { pembelajaran. }\end{array}$ & $\begin{array}{l}\text { Melakukan pendekatan terhadap } \\
\text { siswa dan melaksanakan kegiatan } \\
\text { pembelajaran sesuai tahapan. }\end{array}$ \\
\hline 2 & $\begin{array}{l}\text { Mengenalkan huruf berdasarkan } \\
\text { simbol dengan mengenalkan } \\
\text { bunyi.Namun terdaoat satu siswa } \\
\text { yang tidak mau menirukan. }\end{array}$ & Membuat siswa aktif mengikuti \\
setiap proses pembelajaran.
\end{tabular}

\section{Paparan Data Siklus III}

Proses pembelajaran siklus III sangat kondusif. Siswa mengikuti instruksi dan mendengarkan penjelasan guru. Siswa mampu membunyikan huruf-huruf yang terdapat di bawah gambar. Siswa juga mampu menyusun kata-kata serta memahami arti setiap kata yang disajikan. Berikut paparan penilaian proses siklus III.

Tabel 8 Penilaian Proses Pembelajaran Siklus III

\begin{tabular}{|c|c|c|c|c|c|}
\hline \multirow[t]{2}{*}{ No. } & \multirow[t]{2}{*}{ Aktivitas Yang diamati } & \multicolumn{2}{|c|}{ Pengamat 1} & \multicolumn{2}{|c|}{ Pengamat 2} \\
\hline & & Skor & $\begin{array}{c}\text { Persentase } \\
\text { kemunculan }\end{array}$ & Skor & $\begin{array}{c}\text { Persentase } \\
\text { kemunculan }\end{array}$ \\
\hline 1 & $\begin{array}{l}\text { Aktif dalam kegiatan } \\
\text { pembelajaran }\end{array}$ & 5 & 10 & 5 & 10 \\
\hline 2 & $\begin{array}{l}\text { Bekerja sama dengan } \\
\text { teman }\end{array}$ & 5 & 10 & 4 & 8 \\
\hline 3 & $\begin{array}{ll}\text { Bertanya kepada } & \text { teman } \\
\text { tentang } & \text { materi } \\
\text { pembelajaran } & \\
\end{array}$ & 4 & 8 & 4 & 8 \\
\hline 4 & $\begin{array}{l}\text { Bertanya kepada guru } \\
\text { tentang } \\
\text { pembelajaran }\end{array}$ & 5 & 10 & 5 & 10 \\
\hline 5 & $\begin{array}{l}\text { Menjawab pertanyaan } \\
\text { teman }\end{array}$ & 4 & 8 & 4 & 8 \\
\hline 6 & $\begin{array}{l}\text { Menjawab pertanyaan } \\
\text { guru }\end{array}$ & 5 & 10 & 5 & 10 \\
\hline
\end{tabular}




\begin{tabular}{llcccc}
\hline 7 & $\begin{array}{l}\text { Mengemukakan pendapat } \\
\text { dengan inisiatif sendiri }\end{array}$ & 4 & 8 & 5 & 10 \\
\hline 8 & $\begin{array}{l}\text { Menghargai teman yang } \\
\text { sedang berpendapat }\end{array}$ & 4 & 8 & 4 & 8 \\
\hline 9 & $\begin{array}{l}\text { Membangun sendiri } \\
\text { pengetahuan } \\
\text { dimiliki }\end{array}$ & 4 & 8 & 4 & 8 \\
\hline 10 & $\begin{array}{l}\text { Menyelesaikan tugas } \\
\text { yang sedang diberikan }\end{array}$ & 5 & 10 & 5 & 10 \\
\hline Jumlah & 45 & 90 & 45 & 90 \\
\hline Rata-rata & \multicolumn{3}{c}{45} & & $90 \%$ \\
\hline
\end{tabular}

Hasil observasi siklus III menunjukkan aktivitas siswa dalam mengikuti pembelajaran dengan kriteria sangat baik. Pengamat 1 dan pengamat 2 memberikan skor 45. Hasil observasi terhadap aktivitas siswa pada siklus III mencapai $90 \%$ dengan skor rata-rata 54. Dalam mengikuti proses pembelajaran siswa sangat antusias. Hal tersebut dikarenakan pada umumnya mereka sudah mampu membaca. Dengan demikian mereka berlomba-lomba mendapatkan nilai dari tugas yang diberikan. Nilai siswa siklus III dipaparkan sebagai berikut.

Tabel 9 Hasil Pembelajaran Membaca Permulaan Siklus III

\begin{tabular}{llrcl}
\hline No. & Nama & Nilai & Persentase & Keterangan \\
\hline 1 & AR & 80 & 4.4 & Tuntas \\
\hline 2 & AA & 70 & 3.8 & Tuntas \\
\hline 3 & AD & 75 & 4.1 & Tuntas \\
\hline 4 & AD & 75 & 4.1 & Tuntas \\
\hline 5 & DA & 85 & 4.7 & Tuntas \\
\hline 6 & DL & 75 & 4.1 & Tuntas \\
\hline 7 & FT & 60 & 3.3 & Belum Tuntas \\
\hline 8 & HW & 70 & 3.8 & Tuntas \\
\hline 10 & IU & 75 & 4.1 & Tuntas \\
\hline 11 & KS & 85 & 4.7 & Tuntas \\
\hline 12 & MT & 85 & 4.7 & Tuntas \\
\hline 13 & MI & 80 & 3.8 & Tuntas \\
\hline 14 & RM & 85 & 4.4 & Tuntas \\
\hline 15 & RA & 75 & 4.7 & Tuntas \\
\hline 16 & SB & 75 & 4.1 & Tuntas \\
\hline 17 & SW & 85 & 4.7 & Tuntas \\
\hline 18 & S & 75 & 4.1 & Tuntas \\
\hline 19 & VF & 50 & 2.7 & Belum Tuntas \\
\hline 20 & WM & 75 & 4.1 & Tuntas \\
\hline 21 & YU & 75 & 4.1 & Tuntas \\
\hline & & & &
\end{tabular}




\begin{tabular}{lrrrl}
\hline 22 & YD & 75 & 4.1 & Tuntas \\
\hline 23 & ZA & 80 & 4.4 & Tuntas \\
\hline 24 & SC & 85 & 4.7 & Tuntas \\
\hline Jumlah & 1820 & & \\
\hline \multicolumn{2}{l}{ Rata-rata } & 75,8 & & \\
\hline
\end{tabular}

Berdasarkan tabel di atas diketahui siswa yang memeroleh nilai ketuntasan mencapai $91,7 \%$ dengan peningkatan nilai rata-rata dari 71 menjadi 75,8 . Nilai siswa telah mencapai standart ketuntasan yang ditetapkan. Terdapat dua siswa yang belum tuntas. Hal tersebut dikarenakan kedua siswa mengalami kendala di dalam proses pembelajaran. Satu siswa mengalami kendala tidak mau berbicara ketika di sekolah. Siswa tersebut hanya diam tanpa mau berkata dan sedang dalam proses penangangan sekolah, sedangkan satu siswa lainnya masih senang bermain sendiri di dalam kelas karena usia yang masih di bawah standar usia MI.

\section{KESIMPULAN}

Berdasarkan temuan penelitian dan pembahasan dapat disimpulkan bahwa siswa yag belum mampu membaca lancar mengalami kesulitan dalam proses pembelajaran. Siswa yang belum mampu membaca lancar perlu penanganan khusus agar proses belajar siswa berkelanjutan baik. Penanganan yang dilakukan oleh guru MI Plus Al Islam Dagangan dengan menerapkan membaca permulaan. Siswa dikenalkan dengan simbol dan membunyikan simbol. Langkah berikutnya dengan menyajikan kata-kata yang maknanya dikenali siswa. Siswa kemudian menyusun kata menjadi kalimat. Terjadi peningkatan nilai rata-rata dari pra tindakan ke siklus I dari 51,25 menjadi 56,9. Siklus I diperbaiki dengan adanya siklus II dan nilai ketuntasan siswa mencapai $75 \%$ dengan nilai rata-rata 71 . Tindakan siklus II diperbaiki siklus III dengan nilai ketuntasan mencapai 91,7\% dengan nilai rata-rata 75,8. Terdapat dua siswa yang tidak tuntas dan dalam penanganan sekolah.

\section{DAFTAR PUSTAKA}

Farida, Rahim. (2005). Pengajaran membaca di sekolah dasar. Jakarta: Bumi Aksara.

Iskandarwassid dan D. Suhendar. (2008). Strategi pembelajaran bahasa dan sastra. Bandung: PT Remaja Rosdakarya

Lexy J, Moleong. (2002). Metode penelitian kualitatif. Bandung: PT. Remaja Rosdakarya.

Nafiah, Alfiahesty Choirotun. (2016). Peningkatan kemampuan membaca permulaan melalui metode scramble kalimat siswa kelas ii SDN 1 Sedayu. Jurnal Pendidikan Sekolah Dasar. 24 (5), 289-295 
ST. Y. Slamet. (2008). Dasar-dasar pembelajaran bahasa dan sastra Indonesia di sekolah dasar. Solo: UNS Press.

Subyakto, Nababan. (1993). Metodologi pengajaran bahasa. Jakarta: Gramedia

Richard, Burns. (1971). Method for individualizing instruction, The Macmillan Company. New Jersey: Educational Technology Publicationa Englewood Cliffs

Sitepu. (2012). Penulisan buku teks pelajaran. Bandung: Rosdakarya.

Sugiyono. (2008). Metode penelitian kuantitatif, kualitatif dan R\&D. Bandung: Alfabeta.

Suharsimi, Arikunto. (2008). Dasar-dasar evaluasi pendidikan. Jakarta: Bumi Aksara.

(2002). Prosedur penelitian suatu pendekatan dan praktik. Jakarta: Rineka Cipta. . (2009). Penelitian tindakan kelas. Jakarta: PT Bumi Aksara

Tarigan, Henry Guntur. (1990). Membaca sebagai suatu keterampilan berbahasa. Bandung: Angkasa.

. (2008). Membaca. Bandung: Angkasa 